\title{
ANTI-ATHEROSCLEROTIC EFFECT OF ROSUVASTATIN BY MODULATION OF MGF-E8 AND KLOTHO EXPRESSION
}

\author{
DEYONG YUE ${ }^{1}$, YUNDA JIANG ${ }^{1}$, LIANG CAO $^{2}$, HAIYING SHEN $^{3}$, ZHONGYING YANG $^{1} *$ \\ ${ }^{I}$ Department of Pharmacy, Xinhua Hospital Affiliated to Shanghai Jiao Tong University School of Medicine, Chong Ming \\ Branch, Shanghai, 202150, China \\ ${ }^{2}$ Department of Information, Xinhua Hospital Affiliated to Shanghai Jiao Tong University School of Medicine, Chong Ming \\ Branch, Shanghai, 202150, China \\ ${ }^{3}$ Graduate School, Shanghai University of Traditional Chinese Medicine, Shanghai, 201203, China
}

*corresponding author: yangzhongying_01@sina.com

Manuscript received: January 2018

\begin{abstract}
The aim of this study was to assess the effect of rosuvastatin-mediated MFG-E8 expression on the symptoms of Coronary Heart Disease (CHD) patients with hyperlipidaemia. Two hundred CHD patients with hyperlipidaemia who were admitted to Chong Ming Branch, Xinhua Hospital Affiliated to Shanghai Jiaotong University School of Medicine, China between 2015 and 2017 were selected and divided into two groups. The subjects in the control group received Hypocol ${ }^{\circledR}$ treatment, while those in the experimental group were additionally treated with rosuvastatin $10 \mathrm{mg} /$ day. After 6 weeks of treatment, the differences of low density lipoprotein cholesterol (LDL-C), high sensitive C-reactive protein (hs-CRP), lipoprotein-a (LP (a)), high density lipoprotein cholesterol (HDL-C), MFG-E8, Klotho protein expression and the levels of Th1 and Th2 cell in peripheral blood were assessed. Our results showed that MFG-E8, Klotho protein and HDL-C were higher compared to the control group $(\mathrm{p}<0.05)$. The levels of Th1 cells in both groups decreased, while the levels of Th2 increased. Therefore rosuvastatin can act by altering the expression levels of related proteins, such as MFG-E8 and Klotho and by modifying the levels of Th1/Th2 cells.
\end{abstract}

\section{Rezumat}

Scopul acestui studiu a fost evaluarea efectului rosuvastatinei asupra simptomelor bolii coronariene la pacienții cu dislipidemie, prin modularea expresiei MFG-E8. În studiu au fost introduşi 200 de pacienți cu boală coronariană şi dislipidemie tratați în perioada 2015 - 2017 în spitalul Chongming Branch, Affiliated Xinhua din cadrul Universității Shanghai Jiao Tong, China, împărțiți în două grupuri, un grup de control și un grup de studiu. Cei din grupul de control au primit tratament cu Hypocol R, în timp ce pacienții din grupul de studiu au primit tratament cu rosuvastatină $10 \mathrm{mg} / z i$. După 6 săptămâni de tratament au fost evaluate lipoproteinele cu densitate scazuta (LDL-C), proteina C reactivă înalt sensibilă (hsCRP), lipoproteina-a (LP(a)), lipoproteinele cu densitate înaltă (HDL-C), MFG-E8, proteina Klotho precum și nivelul celulelor Th1 și Th2 din sângele periferic. Rezultatele obținute au arătat că valorile MFG-E8, a proteinei Klotho și a HDL-C au fost semnificativ mai mari comparativ cu grupul control $(\mathrm{p}<0,05)$. După tratament nivelul celulelor Th1 a scăzut în ambele grupuri, în timp ce nivelul celulelor Th2 a crescut semnificativ statistic. Rosuvastatina poate acționa ca și hipolipemiant prin modularea expresiei proteinelor de tipul MFG-E8 și Klotho precum și prin modificarea nivelului celulelor Th1/Th2.

Keywords: rosuvastatin, hyperlipidaemia, MFG-E8, Klotho, Th1, Th2

\section{Introduction}

Coronary Heart Disease (CHD) is caused by myocardial ischemia, hypoxia or necrosis due to vascular stenosis or obstruction resulting from coronary artery atherosclerotic lesions, with serious risks for human life [5]. T lymphocyte can generate a large number of inflammatory cytokines to regulate atherosclerosis. $\mathrm{T}$ lymphocytes are divided into two cells subsets, type I T helper cells (Th1) and type II T helper cells (Th2), according to their biological roles. Th1 which can produce interferon- $\gamma$ (IFN- $\gamma$ ) and interleukin-2 (IL-2), and can promote cellular immunologic response through strengthening the activity of cytotoxic $\mathrm{T}$ cells and natural killer (NK) cells Th2 cells produce IL-4 and IL-10 and mediate humoral immunity through promoting B lymphocyte to produce antibodies. Hyperlipidaemia caused by dyslipidaemia and cholesterol accumulation is one of the complications of coronary heart disease [3, 19, 27]. Metabolic syndrome, characterized by hyperlipidaemia, obesity, type II diabetes mellitus with insulin resistance and hypertension, is associated with non-alcoholic fatty liver [8] or rare disease such us Prader Willi syndrome [4]. Insulin resistance is the link between non-alcoholic fatty liver disease and other pathological conditions including sleep apnoea syndrome and polycystic ovary syndrome, associated with modified 
FARMACIA, 2018, Vol. 66, 3

serum levels of anti-mullerian hormone [6]. It has been established that there is a relationship between the distribution of regional body fat, insulin resistance and pancreas volume in patients with type 2 diabetes mellitus [18, 23, 26].

A growing number of clinical studies have shown that the decreased expression of milk fat globulin epidermal growth factor 8 protein (MFG-E8) and other related proteins expression can accelerate the formation of atheroma plate and lead to CHD and hyperlipidaemia. Ding $\mathrm{H}$ et al. [10] studied the relationship between MFG-E8 and CHD by evaluating the concentrations of MFG-E8 at different stages of coronary heart disease patients and healthy people. $\mathrm{He}$ found that the serum levels of MFG-E8, the severity of coronary artery stenosis and the risk of clinical events are potential biomarkers of vascular complications. Dai W et al. [9] demonstrated that the expression of MFG-E8 in patients with coronary heart disease was lower than that of healthy subjects. In addition, multiple regression analysis showed that MFG-E8 was negatively correlated with hs-CRP levels suggesting that MFG-E8 may be a marker of cardiovascular complications. Klotho gene expresses two kinds of proteins, in the kidney and blood. These proteins play a role in vascular endothelial resistance, cell apoptosis, aging and control the vascular tension. Navarrogonzález et al. [24] found that decreased levels of serum Klotho protein and decreased levels of vascular Klotho protein is correlated with coronary artery disease and its severity. This study aimed to investigate the role of rosuvastatin in restoring MFG-E8 levels, modulating the levels of Th1 and Th2 and the expression of Klotho protein, in hyperlipidaemia CHD patients.

\section{Materials and Methods}

Patients. Two hundred CHD patients with hyperlipidaemia, who were admitted to Chong Ming Branch, Xinhua Hospital Affiliated to Shanghai Jiaotong University School of Medicine, Shanghai, China, between 2015 and 2017, were selected for the study, including 120 male and 80 female patients. They aged between 40 - 60 years old (average $45.1 \pm$ 8.6 years old). They were under treatment with conventional CHD therapy, including nitrate drugs [12], angiotensin-converting enzyme inhibitors and coronary artery dilatation treatment. The subjects were divided into group A (control group) and group B (experimental group), with 60 male patients and 40 female patients in each group. In the control group, patients aged between 41 - 58 years old and received Hypocol $^{\circledR}$. In the experimental group, patients aged from 40 to 60 years old and received rosuvastatin $10 \mathrm{mg} /$ day for 6 weeks. The study has been approved by the Ethical Committee of the hospital, and all subjects signed the informed consent prior to the enrolment in the study.

Inclusion criteria. All patients did not take any lipidlowering drugs or other disruptive drugs one month before being admitted to hospital and had no severe infection, immune system diseases, heart and lung dysfunction, heart rate disorders, liver, kidney, hematopoietic system diseases, mental illness, or allergy to statins.

Reagents and equipment. The materials included RPM1640 cell culture medium (Hyclone, USA), phosphate buffer saline (PBS) (Hyclone, USA), flow cytometry staining buffer (Tianjin Haoyang Biotechnology, China), FIX\&PERM Kit (Tianjin Haoyang Biotechnology, China), centrifuge tube (Corning, USA) and flow cytometry tube (Corning, USA). The instruments included $\mathrm{CO}_{2}$ constanttemperature incubator (Thermo, USA), LD5-2A centrifugal machine (Beijing Medical Centrifuge Factory, China), inverted optical microscope (Olympus, Japan) and flow cytometry (BD FACS Aria, USA). Biochemistry

Blood lipids. Patients were requested to abstain from high-fat food 24 hours before blood collection. Blood samples were collected from fasted patients of the two groups before treatment and 6 weeks after treatment. Afterwards, the serum biomarkers as: total cholesterol (TC), triglycerides (TG), LDL-C and HDL-C protein contents in serum were measured by Hitachi 7170 automatic biochemical analyser [20].

High-sensitivity $C$-reactive protein $(h s-C R P)$. The serum levels hs-CRP was measured by turbidimetric method as previously described [21] using hs-CRP kit (Diazyme Laboratories, Inc., USA).

Serum lipoprotein LP (a), Klotho protein and MFG$E 8$. Serum levels of LP (a), Klotho protein and MFG-E8 were assessed by ELISA as previously described, using Human Lipoprotein a ELISA Kit (Novus Biologicals, Bio-Techne, China), $\alpha$-Klotho ELISA kit (USCN life Science Inc., Wuhan, China), human MFG-E8 ELISA kit (Sigma-Aldrich China, Inc., China), [28].

Isolation of Peripheral Blood Mononuclear Cell (PBMC). $3 \mathrm{~mL}$ of blood collected on heparin sodium anticoagulant was centrifuged at $1000 \mathrm{r} / \mathrm{min}$ for $6 \mathrm{~min}$. After the separation of the supernatant, $2.5 \mathrm{~mL}$ of lymphocyte separation medium were added, in order to separate the PBMC. After PBMC separation the samples were kept in $5 \% \mathrm{CO}_{2}$ atmosphere at room temperature till further analysis.

Th1/Th2. PBMC samples after supernatant removal were treated with RPMI-1640 complete medium supplemented with 10\% Foetal Bovine Serum (FBS). Cells were stimulated with a combination of $250^{*}$ Monensin/BFA and incubated for $4 \mathrm{~h}$ at $37^{\circ} \mathrm{C}$ and $5 \% \mathrm{CO}_{2}$ atmosphere. The fluorescent-coupled monoclonal antibodies used for detection using the flow cytometry method according to manufacturer protocol 
were CD4 PerCP-Cy5 and CD8APC (Tianjin Haoyang Biotechnology, China).

Efficacy criteria for CHD. The angina was evaluated by stress test and electrocardiogram evaluation. If the symptoms of angina completely or basically disappeared and its incidence fell by more than $80 \%$, the effect was considered significant; if the symptoms of angina were alleviated, and the incidence reduced by above $50 \%$, the effect was good; otherwise, the treatment was ineffective.

Efficacy criteria for hyperlipaemia. If TG level reduction rate was over $40 \%$ or TC level reduction rate was over $20 \%$, the effect was considered significant; if TG level reduction rate was over $20 \%$ or TC level reduction rate was over $10 \%$, the effect was good; otherwise, the treatment was ineffective. Statistical analysis. The experimental results were analysed by SPSS 17.0. All data were expressed as mean \pm standard deviation. Logistic regression [22] was used to analyse independent risk factors, $T_{1}$ representing the period before treatment and that $T_{2}$ after treatment. The content of protein in the two periods was recorded, and the statistical significance of the data was studied.

\section{Results and Discussion}

Comparison of the treatment effects
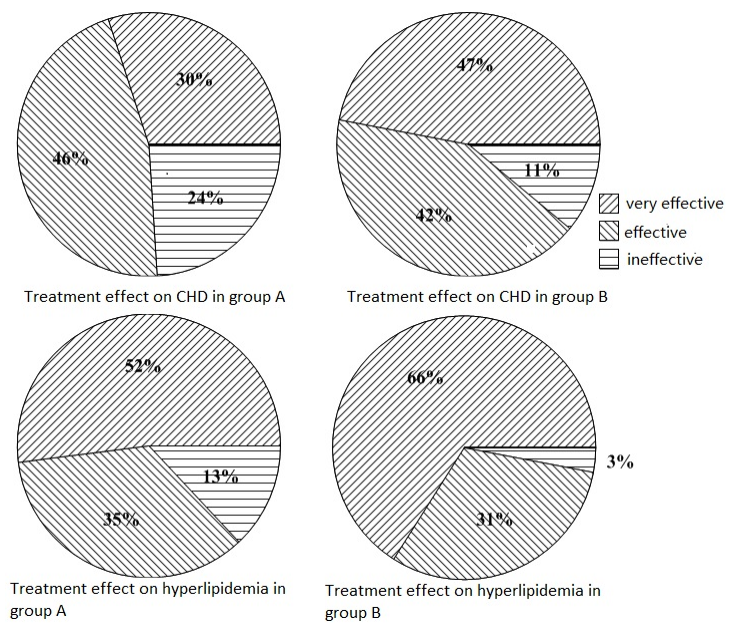

Figure 1.

Comparison of therapeutic effects

As depicted in Figure 1, the comprehensive effective rate was by $89 \%$ higher in group B compared to group A, with statistical significance $(\mathrm{p}<0.05)$, supporting what already was known, that rosuvastatin is effective in treating patients with hyperlipidaemia.

Blood lipids test results

The levels of the lipidic profile are presented in Figure 2.
TC

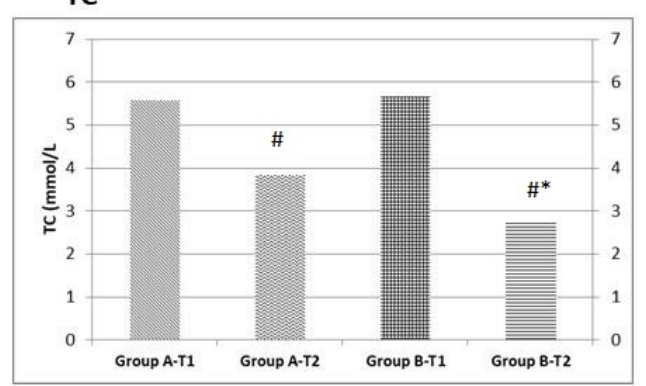

HDL-C

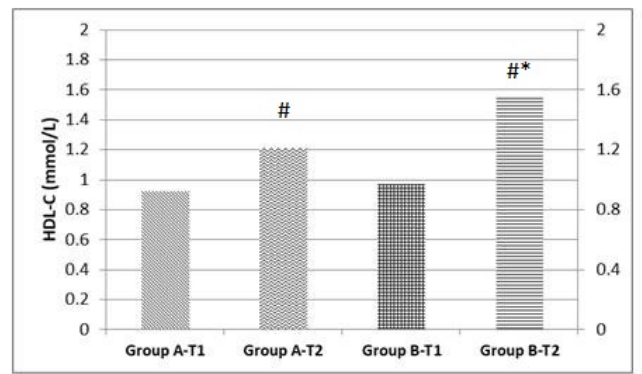

TG

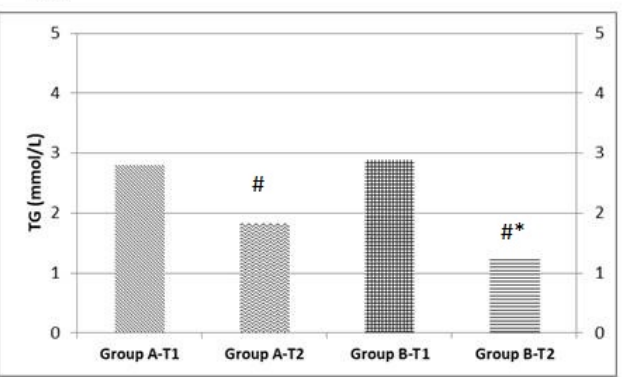

LDL-C

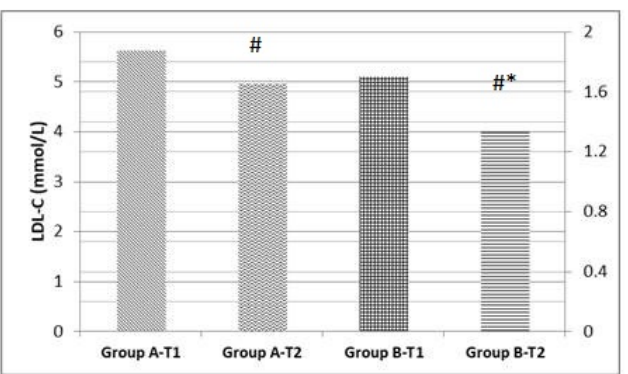

Figure 2.

Comparison of blood lipids between the two groups (\# $\mathrm{p}<0.05 \mathrm{~T}_{1} v s \mathrm{~T}_{2} ;{ }^{*} \mathrm{p}<0.05$ group A $v s$ group B)

As shown in Figure 2, data on blood lipids were not significantly different before treatment in the two groups $(p>0.05)$. As expected for $\mathrm{T}_{2}$, the content of TC, TG and LDL-C in blood, decreased in group $\mathrm{A}$ and $\mathrm{B}$, and the parameters for group $\mathrm{B}$ decreased significantly, while HDL-C was up-regulated in both groups with best results for group B showed a higher degree of up regulation $(\mathrm{p}<0.05)$. 
FARMACIA, 2018, Vol. 66, 3

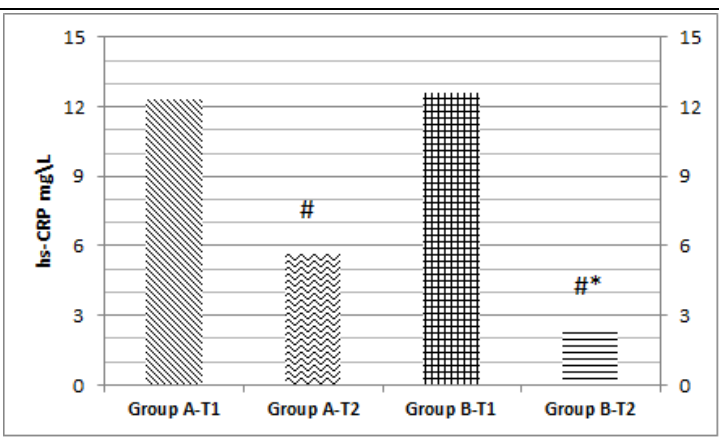

Figure 3.

Comparison of serum hs-CRP levels between the two groups (\# $\mathrm{p}<0.05$ comparing $\mathrm{T}_{1}$ with $\mathrm{T}_{2} ; * \mathrm{p}<0.05$ comparing group $\mathrm{A}$ with group $\mathrm{B}$ )
Serum hs-CRP levels

As shown in Figure 3, hs-CRP content in $\mathrm{T}_{1}$ was not statistically significantly different between the two groups $(p>0.05)$. In $T_{2}$, levels of hs-CRP in the control group significantly decreased from $12.35 \pm$ $1.88 \mathrm{mg} / \mathrm{L}$ to $5.63 \pm 1.01 \mathrm{mg} / \mathrm{L}(\mathrm{p}<0.05)$ while in group $\mathrm{B}$ it decreased from $12.58 \pm 2.13 \mathrm{mg} / \mathrm{L}$ to $2.26 \pm 0.46 \mathrm{mg} / \mathrm{L}(\mathrm{p}<0.05)$. The levels of hs-CRP was significantly reduced in group B compared to group A after treatment $(\mathrm{p}<0.05)$.

Serum lipoprotein LP (a), Klotho protein and $M F G$-E8. Serum lipoprotein LP (a), Klotho protein and MFG-E8 test results are shown in Table I.

Table I

Comparison of serum lipoprotein LP (a), Klotho protein and MFG-E8 between the two groups

\begin{tabular}{|l|c|c|c|c|}
\hline Group & \multicolumn{2}{|c|}{$\mathrm{A}$} & \multicolumn{2}{c|}{$\mathrm{B}$} \\
\hline Time & $\mathrm{T}_{1}$ & $\mathrm{~T}_{2}$ & $\mathrm{~T}_{1}$ & $\mathrm{~T}_{2}$ \\
\hline MFG-E8 $(\mathrm{ng} / \mathrm{mL})$ & $204.90 \pm 4.93$ & $297.88 \pm 12.03^{\#}$ & $194.88 \pm 5.03$ & $507.85 \pm 24.12^{\#^{*}}$ \\
\hline LP (a) $(\mathrm{mg} / \mathrm{L})$ & $375.42 \pm 38.22$ & $175.65 \pm 20.36^{\#}$ & $365.23 \pm 35.12$ & $144.23 \pm 23.42^{\#^{*}}$ \\
\hline Klotho protein $(\mathrm{pg} / \mathrm{mL})$ & $27.43 \pm 2.86$ & $32.48 \pm 3.78 \#$ & $27.32 \pm 2.85$ & $41.63 \pm 5.14^{\#^{*}}$ \\
\hline
\end{tabular}

$\# \mathrm{p}<0.05$ comparing $\mathrm{T}_{1}$ with $\mathrm{T}_{2} ;{ }^{*} \mathrm{p}<0.05$ comparing group $\mathrm{A}$ with group $\mathrm{B}$

As shown in Table I, the expression levels of MFGE8 and Klotho protein in groups $\mathrm{A}$ and $\mathrm{B}$ were similar before treatment $(\mathrm{p}>0.05)$. After treatment, the expression levels of MFG-E8 and Klotho protein in group B was significantly increased. The expression level of MFG-E8 increased from $194.88 \pm 5.03 \mathrm{ng} / \mathrm{L}$ to $507.85 \pm 24.12 \mathrm{ng} / \mathrm{L}$, and the expression level of Klotho protein increased from $27.32 \pm 2.85 \mathrm{pg} / \mathrm{L}$ to $41.63 \pm 5.14 \mathrm{pg} / \mathrm{L}$; the differences for group A showed statistical significance $(\mathrm{p}<0.05)$. The expression levels of MFG-E8 and Klotho protein of both groups increased significantly after treatment, and the differences had statistical significance $(p<0.05)$. There was no significant difference in LP (a) level between the two groups before treatment $(p>0.05)$. After treatment, LP (a) level decreased from $365.23 \pm$ $35.12 \mathrm{mg} / \mathrm{L}$ to $144.23 \pm 23.42 \mathrm{mg} / \mathrm{L}$ in group B and decreased from $375.42 \pm 38.22 \mathrm{mg} / \mathrm{L}$ to $175.65 \pm$
$20.36 \mathrm{mg} / \mathrm{L}$ in group A $(\mathrm{p}<0.05)$. The difference of LP (a) level was significant before and after treatment in both groups $(\mathrm{p}<0.05)$.

Percentage of Th1 and Th2. It can be seen from Table II and Figures 4-6 that the percentage of Th1 and Th2 of group A and B were not significantly different before treatment $(p>0.05)$. After 6 weeks of treatment, the percentage of Th1 decreased in both groups, but the percentage of Th2 increased, and the percentage of Th1 and Th2 of the two groups before and after treatment were significantly different $(p<0.05)$. The percentage of Th1 of group B was lower than that of group A $(19.07 \pm 2.09 \%$ vs. $22.14 \pm$ $1.97 \%$ ), while the percentage of Th2 of group B was higher than that of group A $(1.72 \pm 0.13 \% v s .1 .44 \pm$ $0.14 \%)$; the differences were statistically significant $(\mathrm{p}<0.05)$.

Table II

The changes in percentage of Th1 and Th2 in the two groups

\begin{tabular}{|l|c|c|c|c|}
\hline Group & \multicolumn{2}{|c|}{ Group A } & \multicolumn{2}{c|}{ Group B } \\
\hline Time & $\mathrm{T}_{1}$ & $\mathrm{~T}_{2}$ & $\mathrm{~T}_{1}$ & $\mathrm{~T}_{2}$ \\
\hline Th1 cells (\%) & $27.04 \pm 1.85$ & $22.14 \pm 1.97^{\#}$ & $27.01 \pm 1.87$ & $19.07 \pm 2.09^{\#^{*}}$ \\
\hline Th2 cells (\%) & $1.12 \pm 0.17$ & $1.44 \pm 0.14^{\#}$ & $1.13 \pm 0.16$ & $1.72 \pm 0.13^{\# *}$ \\
\hline
\end{tabular}

$\# \mathrm{p}<0.05 \mathrm{~T}_{2} v s \mathrm{~T}_{1} ; * \mathrm{p}<0.05$ group A $v s \mathrm{~B}$ 


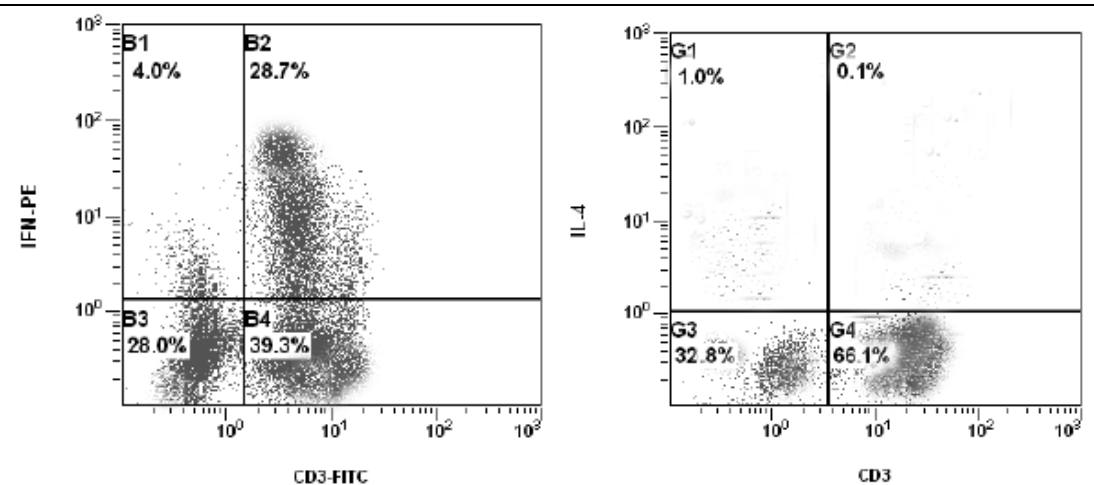

Figure 4.

Percentage of Th1 and Th2 cells before treatment (left: Th1; right: Th2)
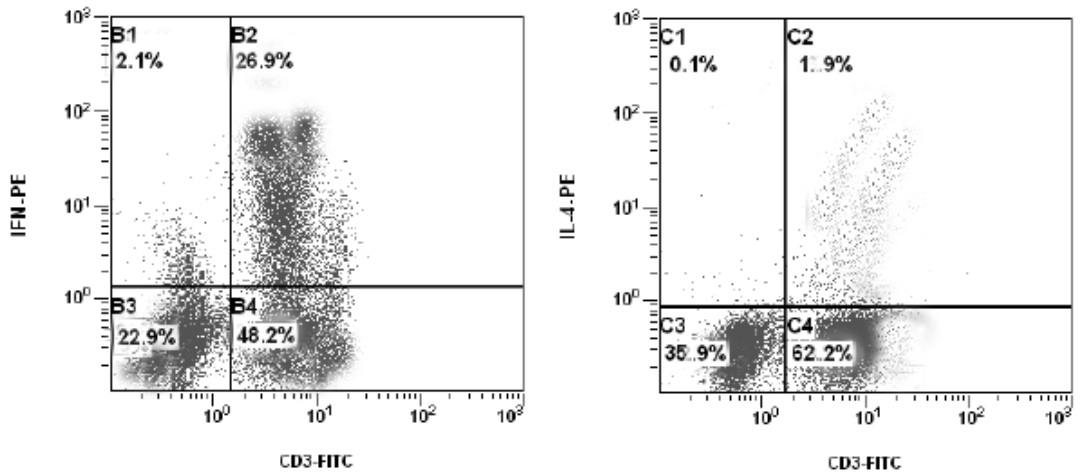

Figure 5.

Percentage of Th1 and Th2 cells in group A after treatment (left: Th1; right: Th2)

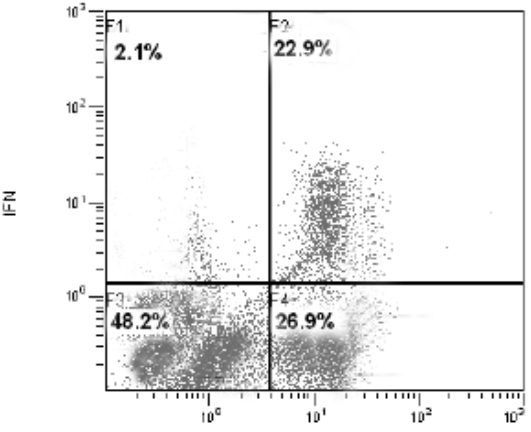

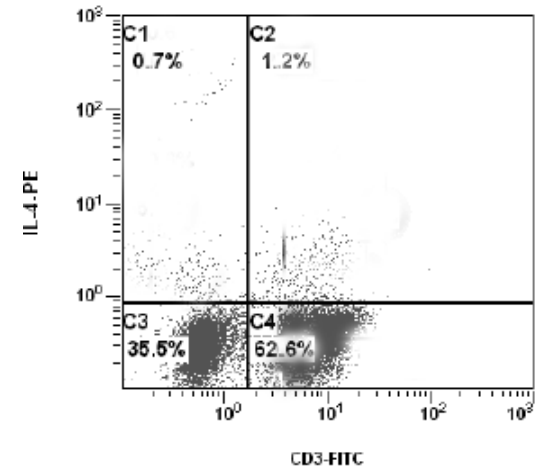

Figure 6.

Percentage of Th1 and Th2 cells in group B after treatment (left: Th1; right: Th2)
In recent years, more and more people tend to suffer from cardiovascular diseases. Coronary atherosclerosis is one of the main causes of CHD. Hyperlipidaemia is an independent risk factor for CHD and it is caused by excessive levels of proteins such as hs-CRP and LP (a) due to the lipid rise in the plasma [10]. Lipids in human plasma are essential metabolic biomolecules and they can easily cause a variety of sudden illness [7] in a high level. CHD combined with hyperlipidaemia is one of the most common comorbidity, which poses a great threat to the human body. Hence, it is urgent to find new effective drugs. Rosuvastatin is one of the most common lipidlowering drugs $[1,2,16]$, which can effectively inhibit the formation of HMG-CoA reductase to reduce the body's cholesterol production. It is commonly used in the treatment of dyslipidaemia, although cases of severe myopathy have been reported especially in elderly patients treated with high doses of statins [14]. Moreover, rosuvastatin can inhibit inflammatory responses [17]. As a pro-inflammatory biomarker, hsCRP can reflect the occurrence of vascular inflammation in patients [13]. Rosuvastatin can effectively inhibit the production of inflammatory factors, thereby reducing the risk of CHD in patients. The decreased expression of MFG-E8 and LP (a) can accelerate the accumulation of apoptotic membrane fragments and the induction of atherosclerosis. Therefore, the 
content of MFG-E8 and LP (a) has important values for evaluating the severity of CHD patients with hyperlipidaemia $[15,25]$. Klotho protein as an important anti-aging factor in human body can protect vascular endothelial cells, i.e. slow the aging and apoptosis of vascular endothelial cells, and effectively inhibit atherosclerosis.

In this study, serum lipoprotein LP (a), Klotho protein and MFG-E8 levels were analysed in order to assess their implication in rosuvastatin hypolipaemiant mechanism of action. Rosuvastatin up-regulated the levels of MFG-E8 and Klotho protein and decreased the content of LP (a) in patients, leading to reduced risks of developing CHD associated complications. It was found that the expression level of Klotho protein in group B was higher than that of group A after treatment $(\mathrm{p}<$ 0.05 ), indicating that rosuvastatin can effectively decrease the levels of serum Klotho protein.

The percentage of Th1 and Th2 cells is misbalanced in the patients with CHD, which may induce severe heart events. The analysis on the percentage of Th1 and Th2 in this study suggested that the Th1 percentage decreased while the percentage of Th2 increased in the two groups after treatment $(\mathrm{p}<0.05)$; compared to the control group, the patients with rosuvastatin had more obvious changes, rosuvastatin modulating Th1/Th2 levels, as part of the immune system.

\section{Conclusions}

Rosuvastatin can reduce the levels of $\mathrm{TC}, \mathrm{TG}$, LDL-C and hs-CRP by changing the expression of MFG-E8 and other proteins and regulating some components of the immune system, namely the percentage of Th1 and Th2 cells. Upregulation of MFG-E8, Klotho protein and LP (a) levels may effectively reduce the incidence of hyperlipidaemia in patients with CHD. This study provides a new scientific reference for the use of rosuvastatin in the treatment of patients with CHD.

\section{References}

1. Akinkuolie AO, Glynn RJ, Ridker PM, Mora S, Protein glycan side-chains, rosuvastatin therapy, and incident vascular events: An analysis from the JUPITER trial. Circulation. 2014; 130: A17731A17731.

2. Albert MA, Glynn RJ, Fonseca FA, Lorenzatti AJ, Ferdinand KC, Fadyen JG, Ridker PM, Race, ethnicity, and the efficacy of rosuvastatin in primary prevention: the Justification for the Use of Statins in Prevention: an Intervention Trial Evaluating Rosuvastatin (JUPITER) trial. $\mathrm{Am}$ Heart J., 2011; 162(1): 106-114.

3. Anderson TJ, Grégoire J, Hegele RA, Couture P, Mancini GB, McPherson R, Francis GA, Poirier P, Lau DC, Grover S, Genest J Jr, Carpentier AC,
Dufour R, Gupta M, Ward R, Leiter LA, Lonn E, Ng DS, Pearson GJ, Yates GM, Stone JA, Ur E, 2012 update of the Canadian Cardiovascular Society guidelines for the diagnosis and treatment of dyslipidemia for the prevention of cardiovascular disease in the adult. Can J Cardiol., 2013; 29(2): 151-167.

4. Badiu C, Marginean O, Current status and perspectives in the treatment of Prader-Willi syndrome. Exp Opin on Orphan Drugs. 2014; 2(4): 337-347.

5. Bendinelli B, Masala G, Saieva C, Salvini S, Calonico C, Sacerdote C, Agnoli C, Grioni S, Frasca G, Mattiello A, Chiodini P, Tumino R, Vineis P, Palli D, Panico S, Fruit, vegetables, and olive oil and risk of coronary heart disease in Italian women: the EPICOR Study. Am J Clin Nutr., 2011; 94(1): 275-283.

6. Bothou A, Koutlaki N, Iatrakis G, Mastorakos G, Tsikouras P, Liberis V, Galazios G, Liberis A, Lykeridou A, Zervoudis S, Antimullerian Hormone as Indicator of Ovarian Dysfunction. Acta Endo (Buc.), 2017, 13 (2): 237-245 -16

7. Braje DA, Kirchner M, Fortier T, Mbele V, Fox R, Weinery AM, Diddams SA, Hollberg L, Biological, clinical and population relevance of 95 loci for blood lipids. Nature. 2010; 466(7307): 707.

8. Cioboată R, Găman A, Traşcă D, Ungureanu A, Docea AO, Tomescu P, Gherghina F, Arsene AL, Badiu C, Tsatsakis AM, Spandidos D, Drakoulis N, Călina D, Pharmacological management of nonalcoholic fatty liver disease: Atorvastatin versus pentoxifylline. Exp Ther Med., 2017; 13(5): 23752381

9. Dai W, Li Y, Lv YN, Wei CD, Zheng HY, The roles of a novel anti-inflammatory factor, milk fat globule-epidermal growth factor 8 , in patients with coronary atherosclerotic heart disease. Atherosclerosis, 2014; 233(2): 661-665.

10. Ding H, Dai W, Xie S, Jin D, Ning Y, Tu J, Antiinflammatory Effect and Diagnostic Value of Serum MFG-E8 in Aged Coronary Atherosclerotic Heart Disease. Med J Wuhan Univ., 2015; 36(2): 274-277.

11. Drechsler M, Megens RT, Van ZM, Weber C, Soehnlein O, Hyperlipidemia-triggered neutrophilia promotes early atherosclerosis. Circulation, 2010; 122(18): 1837-1845.

12. Du J, Yang W, Yi DH, Xie YM, Zhuang Y, Chen Q. Analysis of using Danhong injection to treatment coronary heart disease patients medicines based on real world HIS database. China J Chinese Materia Medica, 2011; 36(20): 2821.

13. Ebrahimi M, Heidari-Bakavoli AR, Shoeibi S, Mirhafez SR, Moohebati M, Esmaily H, Ghazavi H, Saberi Karimian M, Parizadeh SMR, Mohammadi M, Mohaddes Ardabili H, Ferns GA, Ghayour-Mobarhan M, Association of Serum hs-CRP Levels With the Presence of Obesity, Diabetes Mellitus, and Other Cardiovascular Risk Factors. J Clin Lab Anal., 2016; 30(5): 672-676.

14. Elena C, Cristina DC, Salvatore T, Silvia G, Giovanni L, Giuseppe R, Carmela I, Filippo P, Agata G, Valerio FP, Stefano P, Pietro G, Giulia FS, Santo SS, A severe myopathy case in aged patient treated with high statin dosage. Tox Rep., 2017; 4: 438-440. 
FARMACIA, 2018, Vol. 66, 3

15. Fricker M, Neher JJ, Zhao JW, Théry C, Tolkovsky AM, MFG-E8 mediates primary phagocytosis of viable neurons during neuroinflammation. $J$ Neurosci., 2012; 32(8): 2657-2666.

16. Glynn RJ, Koenig W, Nordestgaard BG, Shepherd J, Ridker PM, Rosuvastatin for primary prevention in older persons with elevated C-reactive protein and low to average low-density lipoprotein cholesterol levels: exploratory analysis of a randomized trial. Ann Intern Med., 2010; 152(8): 488-496.

17. Jiao Y, Hu F, Zhang Z, Gong K, Sun X, Li A, Liu N, Effect of rosuvastatin dose-loading on serum sLox-1, hs-CRP, and postoperative prognosis in diabetic patients with acute coronary syndromes undergoing selected percutaneous coronary intervention (PCI). Int J Clin Exp Med., 2015; 8(11): 21565-21571.

18. Johar D, Maher A, Aboelmagd O, Hammad A, Morsi M, Warda HF, Awad HI, Mohamed TA, Zaky S, Whole-food phytochemicals antioxidative potential in alloxan-diabetic rats. Tox Rep., 2018; 5: 240-250.

19. Ilieşiu AM, Pârvu I, Hodorogea AS, Nanea IT, Popescu AC, Perspectives in lipid lowering therapy. New therapies targeting LDL - cholesterol. Farmacia, 2018; 66(1): 8-17.

20. Liu CC, Hung CL, Shih SC, Ko HJ, Lu YT, Wu YJ, Cheng HY, Hu KC, Yeh HI, Chang RE, Agerelated Differences in the Clinical Presentation, Associated Metabolic Abnormality, and Estimated Cardiovascular Risks from Nonalcoholic Fatty Liver Disease: A Cross-sectional Study from Health Evaluation Center in Taiwan. Inter J Gerontol., 2010; 4(4): 184-191.

21. Liu Y, Pan KL, Wang C, Wei LS, Shen JS, Research on Determination of Argentum ions in the Waste Water of Film by Resonance Light Scattering Turbidimetric Method. J Sichuan Normal Univ., 2012; 29(1): 311-317.
22. Mood C, Logistic Regression: Why We Cannot Do What We Think We Can Do, and What We Can Do About It. Eur Sociological Rev., 2010; 26(1): 67-82.

23. Cioates Negut C, Stefan-van Staden RI, Ungureanu EM, Udeanu DI, Stochastic sensors designed for assessment of biomarkers specific to obesity. $J$ Pharmac Biomed Analysis, 2016; 128: 280-285.

24. Navarrogonzález J F, Donatecorrea J, Muros de Fuentes M, Pérez-Hernández H, Martínez-Sanz R, Mora-Fernández C, Reduced Klotho is associated with the presence and severity of coronary artery disease. Heart, 2014; 100(1): 34.

25. Norata GD, Ballantyne CM, Catapano AL, New therapeutic principles in dyslipidaemia: focus on LDL and Lp(a) lowering drugs. Eur Heart J., 2013; 34(24): 1783-1789.

26. Oz II, Bilici M, Serifoglu I, Karakaya Arpaci D, Buyukuysal MC, Bayraktaroglu T, Association of Pancreas Volume and Insulin Resistance with Abdominal Fat Distribution in Type-2 Diabetes as Evaluated by Computed Tomography. Acta Endo (Buc.), 2017; 13(2): 168-173.

27. Parepa IR, Suceveanu AI, Mazilu L, Mohamed A, Niţă D, Tuţă LA, Preventing cardiac complications after non-cardiac non-vascular surgery by using perioperative statin therapy - a prospective study in Constanta County, Romania. Farmacia, 2017; 65(1): 120-124.

28. Yamazaki Y, Imura AI, Urakawa I, Shimada T, Murakami J, Aono Y, Hasegawa H, Yamashita T, Nakatani K, Saito Y, Okamoto N, Kurumatani N, Namba N, Kitaoka T, Ozono K, Sakai T, Hataya H, Ichikawa S, Imel EA, Econs MJ, Nabeshima Y, Establishment of sandwich ELISA for soluble alphaKlotho measurement: Age-dependent change of soluble alpha-Klotho levels in healthy subjects. Biochem Biophys Res Commun., 2010; 398(3): 513-518. 